\title{
Valiant, vital and virtuous - A time-snap review
}

\author{
Matti Itkonen \\ University of Jyväskylä, Finland
}

\begin{abstract}
A time-snap review - moments captured pictorially - means the creation of multi-layered observation. The enquiring gaze then extends beyond the present moment: to its existential roots. However, it is not a question of presenting an historical list, a collection of topics of various types and periods. Of course, understanding the present also requires knowledge of the people and events of the past. In this way it also becomes possible to study the recurring nature of existence. Can war-related travel also count as cultural travel? Is it possible to talk about war tourism? Presumably, in many countries the answer to this will be positive. It relates to the history of ideas and also to national sentiment. This kind of cultural education may be indoctrinating in character, with the goal of insinuating into people's minds the concept of the incomparable excellence of their own nationality. The spirit of the 2010s contains shades of indoctrination. Fortunately, alongside this struggle to impress, education for democracy is also present. Photographs and poetry are powerful media, helping us to create a nostalgia for being. Then, too, a longing for the past is awakened. It is here that a philosophy of yearning or wistfulness is needed, providing an exploratory tool for analyzing the nature of the individual and the community. Modernity needs philosophical poet-travellers. They are adept at loving the wisdom of travel.
\end{abstract}

Keywords: valiant, vital, virtuous, time-snap, review

\section{Introduction}

At this point the author demands his readers' flexibility as he indulges in wordplay and neologistic adventuring. The sporty disport themselves. The cheerful cheer. The just adjust. Words wordify and enword. Language enlanguages. A picture pictures, depicts and picturizes. For the researcher, each of these features is a useful and practical tool. They also highlight an important means of self-expression. In other words, without them the philosophical essayist is unable to convey his thoughts to others. He falls silent, is struck dumb. Simultaneously the existential landscape existing between people is also muted. The time-snap remains empty of content and form. This cannot be allowed to happen. Otherwis the review becomes superfluous.

First, a person is a "what" and only after that a "who". He develops and is developed. So, is a person constantly something that will only be realized in the future? Is he seen merely as a blank that has to be shaped, ready and suitable for a later stage? And in what way will he be more ready and more suitable than at that initial stage?

At the turning points of existence the benefit to society may matter much more than the good of the individual. Then it is beneficial to think of people as a uniform, unanimous and like-minded group which is absolutely committed to promoting and achieving shared goals. In this way a powerful sense of nationality may also come about. Perhaps often we could also talk about national pride. Nevertheless, this should not be allowed to mutate into arrogance or chauvinism

When school students come to mean in the first instance future soldiers or members of the Lotta Svärd (the women's auxiliary defence force), then what kind of understanding of humanity, honesty and responsibilty is actually connected to the situation? Deeper analysis now requires a photographic perspective on the topic. 


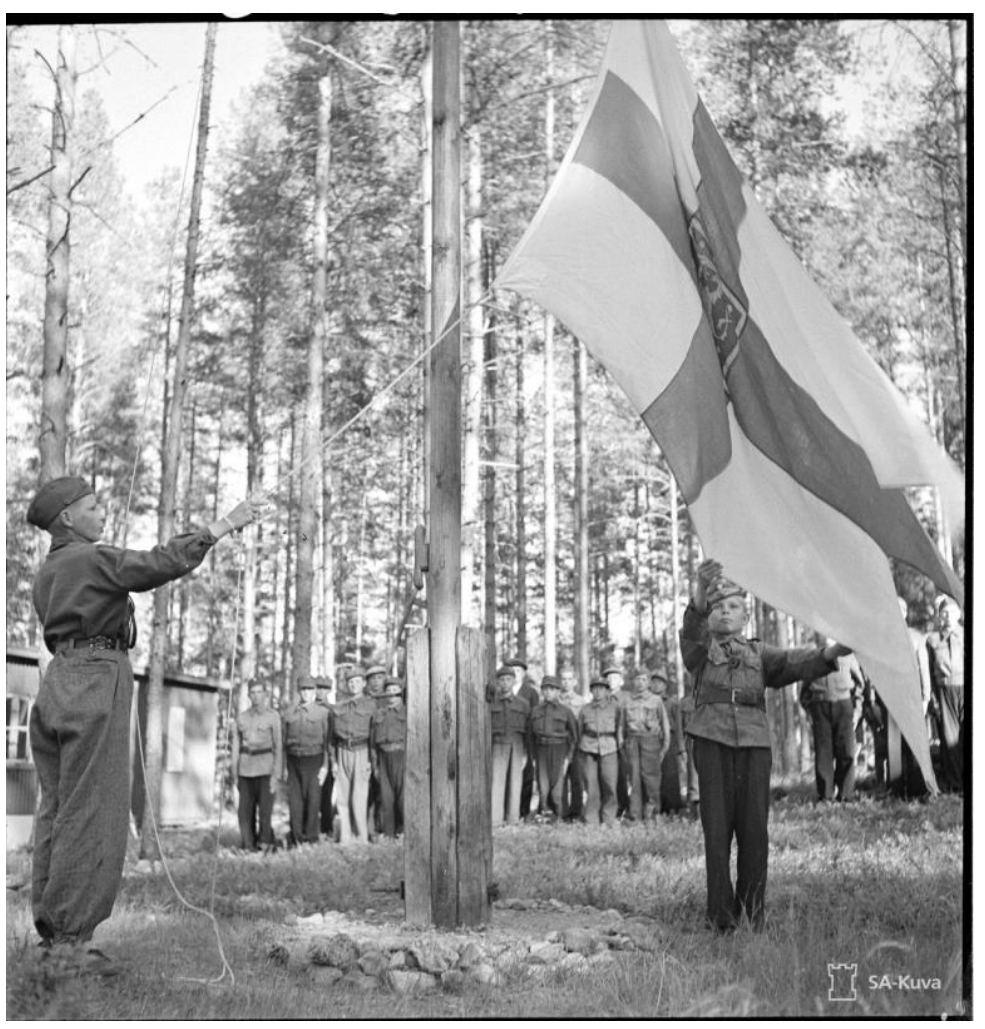

Photograph 1. The obligation of uniform and flag. ${ }^{1}$

What sort of educational goals were there during wartime? Whose interests might they have best served? What do written documents have to say about this? A good place to start the search for answers is J. E. Salomaa's book The Direction and the Road (1942). The book's succinct supplementary title was "The basics of civic education". True enough, the theme was not only bound up with the years of the continuation war, but extended timelessly into the following decade. Which is why it is still justified to say that the war and subsequent period of rebuilding were similar in terms of their educational ideals. They probably also laid the foundation for the educational and cultural thinking of the 21 st century.

The main chapter of Salomaa's book is entitled "The Individual and the community". The idea of the obligating nature of uniform and flag would not be possible without the close mutual interaction of the individual and the community. They have to be powerfully intertwined one within the other so that a duality can be talked about as a single oneness. Professor Salomaa wrote about the topic and raised additional considerations: "Our spiritual being, our most precious side, has developed through contact and interaction with other people. We have acquired our opinions, our thoughts, our technology, our developed feelings, even our moral nature, from our environment, both the narrower and the broader. (..) Human culture has only been able to develop in society thanks to the collaborative activities of people - both past and present Only in society has humanity been able to develop agriculture, trade, industry and intellectual culture." (Salomaa, 1942, p. 159.)

As the author of this time-snap review I make so bold as to suspect that in photograph one some kind of human testing is under way. You could, then, assume that an experimental existential mood pervades the shot. The uniform and the swallow-tail national flag demand dignity. The boys' expressions were serious. They have probably committed themselves wholeheartedly and zealously to defending the nation. Alone, such dedication to anything at all would not have been possible. It required other people, interaction and collaboration. Only then is it perhaps possible to talk about the creation of some kind of culture. 
Over time flags have been hoisted for different ideals, flying simultaneously in support for both good and bad standpoints. And always educational objectives have also been associated with these endeavours. At the same time it is probable that in importance the interests of the community exceed those of the individual. Scouting, sports clubs, religions, political organizations, various ideologies, trade unions and trends in musical style are examples of things inciting fanaticism. It is at these moments too that the power of shared solidarity has been the incitement to all activity. Acting alone would not have produced anything of significance.

For this reason even the soldier lads in photograph one were an essential part of society. They reinforced national sentiment and the spiritual essence of the nation. In this way it was also possible to sustain trust in a bright future.

\section{Sport}

The following sample shot from the time-snap review shows Finnish baseball, which has also been called the Finnish national game. It was developed by Lauri Pihkala, who is usually given the additional moniker or nickname of 'Tahko' (= grindstone). It would seem that even behind every sports-related thought there is some kind of militaristic or other ideological aim. In other words, then physical exercise is merely of instrumental value on the pathway to an ultimate educational or propaganda objective. Here again, the interests of the community are prioritized over those of the individual. (See also Pihkala, 2018.)

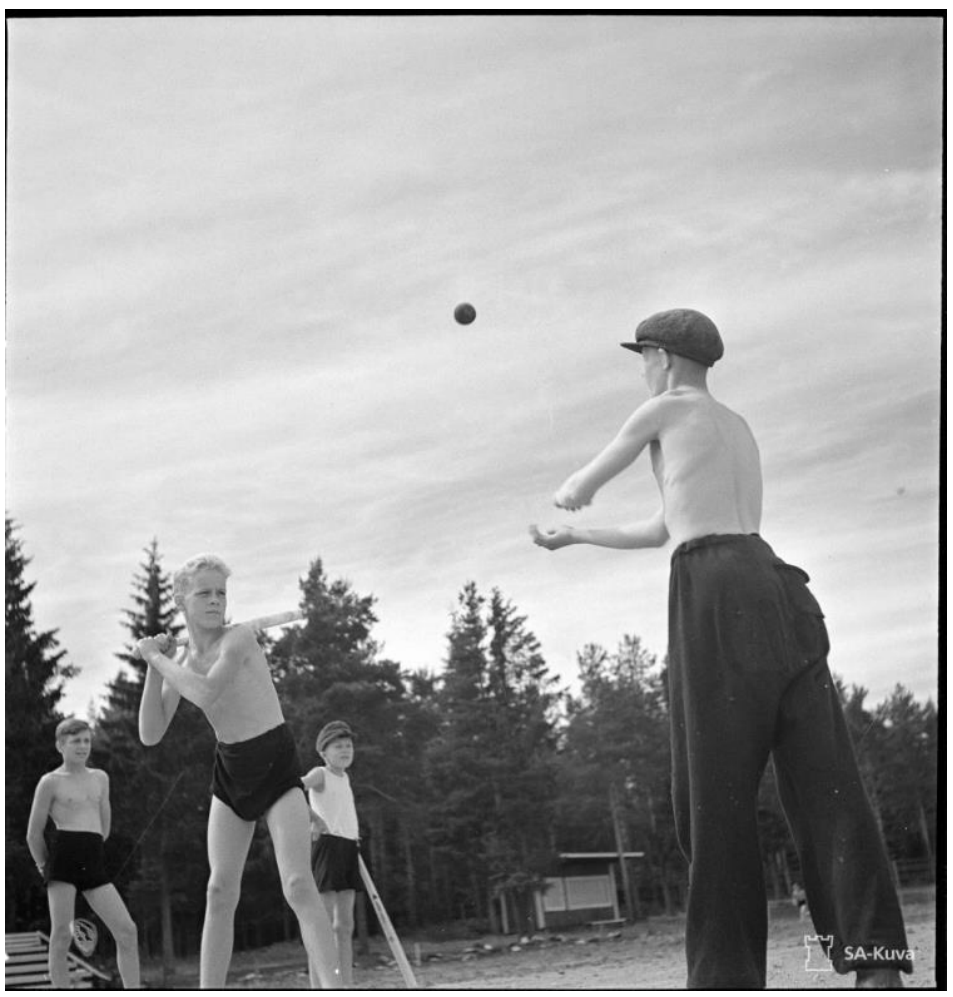

Photograph 2. Sport creates the sporting spirit.

What do written documents have to say in support of the time-snap review's credibility? An essential work that links together several decades is Aukusti Salo's Introduction to general education. It appeared posthumously after professor Salo's death in 1952. Even though this was a time of rebuilding and the year of the Helsinki Olympics, the book lends itself to an examination of the continuation war period. 
Salo drew attention in an interesting way to the educational significance of competition and prize-winning: "Besides being a factor in the development of personality, competition has, with full justification, also been called the life nerve of social and cultural life as well as of all progress. (..) The community is an important reinforcer of the competitive drive, even amongst those who are growing up, although the need for development-promoting activity is often so powerful in them that this is enough in itself to generate pleasure. Children don't often get disheartened if they lose as long as they have been able to act and exert themselves. Nevertheless, competition increases energy, strengthens the will, enhances performance and revitalizes self-assertiveness and sense of worth - understandably only to a certain individual limit. In addition to everything else, competition always presupposes physical and mental fitness." (Salo, 1952, pp. 255-256.)

Photograph two arouses a feeling of sadness in this one-man time-snap review research team. The boys are full of joy, enthusiasm and energy and they seem to be totally immersed in their game of baseball. They were probably quite unaware of any possible educational objectives in what they were doing. And that was the way it was supposed to be. Indeed, it may well be that our national game was able to function as a "life nerve" of cultural and communal life, in accordance with Salo's characterization. The boys in the picture are still children. Often an element of indoctrination is associated with education at periods of existential change. Then the activity is craftily insinuated, manipulating towards some specific direction. Under the guise of play and sport the boys were probably being steered towards the martial. No doubt this didn't bother them. Presumably the mere excitement of competing was enough to inspire dedicated involvement. And that was already reward enough.

Should baseball then engender sportliness or heroic courage? Was the cloth-capped young pitcher perhaps thinking of a hand grenade as he tossed the ball into the air? That seems quite hard to believe. If playful recreation strengthened the will and increased energy, then so what? Why or for what purpose were these, or an invigorated sense of personal worth, actually needed? Could the boy standing in the background with his military headgear have been thinking about conditions at the front? Was he possibly drawing a parallel between the baseball bat in his hand and a weapon? Probably not.

This situation with the boys' increasing physical and mental fitness benefited the community. Or at least it was supposed to increase. For the players themselves it was probably enough to be caught up in the game and enjoy the heat of a summer's day. Of course, to them the time also meant a summer of childhood and togetherness. In fact, it would be the perfect title for the whole photograph: "A Summer of Childhood and Togetherness". Photograph two is indeed like an existential work of art, a moment shared together beneath Finland's summer skies. The eternal and the ephemeral are captured in one and the same picture.

\section{Provisions}

As far as food and feeding were concerned, the most important works were the Lotta Svärd Catering Handbook and the Military Cookbook. Food was and continues to be an important component of existence in many senses. The first edition of the Lotta Svärd Catering Handbook was published in 1928 while the Military Cookbook appeared in 1922. Here, too, we must resort to the narrative power of the photograph. A sufficiently high-quality time-snap review is not feasible in any other way. 


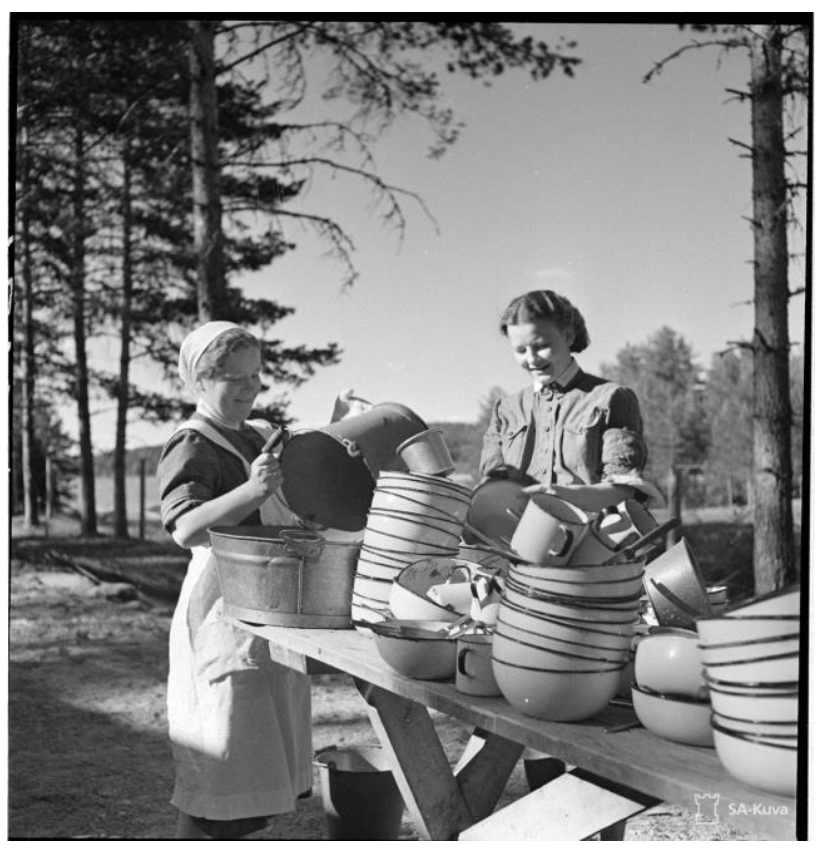

Photograph 3. Dedication to a common cause.

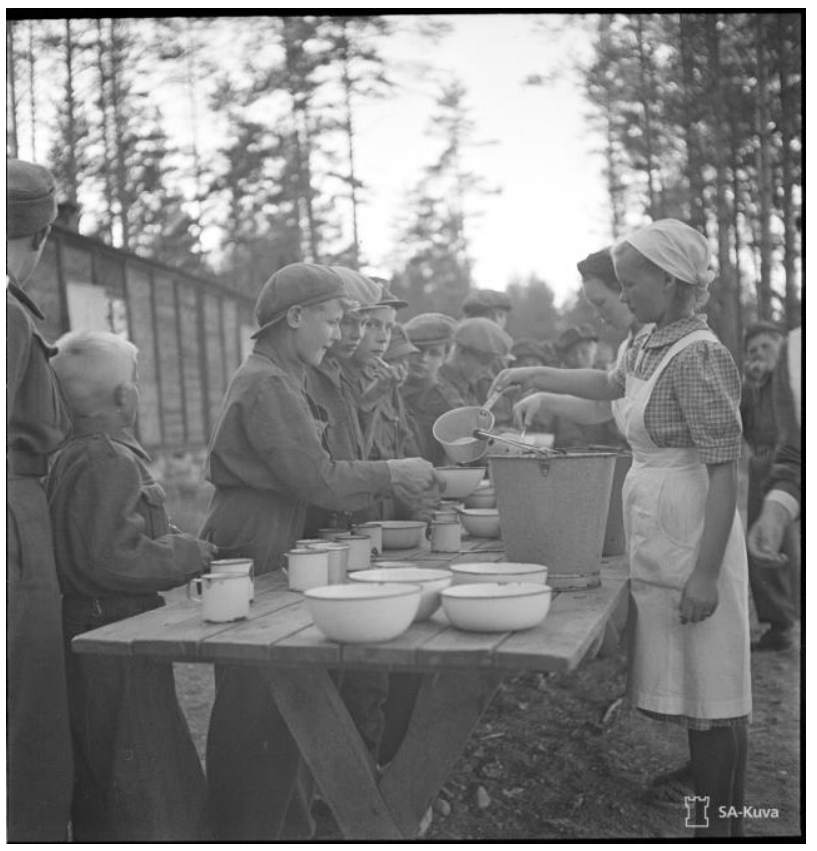

Photograph 4. Mealtime. 
The handbook provides a very detailed guide to the activities of the Lotta Svärd caterers. The following items to do with catering work are mentioned: preparatory tasks; preparing a meal; serving and clearing up (see Malmgren 1939,53). The Military Cookbook, on the other hand, precisely specifies requirements for the kitchen and its fittings. The need for cleanliness is particularly stressed: "In every dining group the kitchen section should include at least two rooms, namely a kitchen and a special dish-washing room since, if the cleaning of all the dishes takes place in the kitchen itself, it may all too easily happen that the necessary cleanliness is not always taken into account in the preparation of food" (Sotilas, 1922, p. 20).

The smiling Lotta Svärd members bring a warm feeling to photograph 3: their whole being gives the impression that they are in harmony with the tranquility of summer and nature. The totality conveys the sincerity of their dedication to a common cause. The photograph was taken when the follow-up tasks were underway, i.e. washing the dishes. After all, the importance of this phase was explicitly emphasized in the instructions. Practicality was probably also an essential factor, which is why the dishes were made of metal. Tinware was an excellent choice of material, given its practicality and the simplicity of washing it. Carrying, washing-up and eating the meal itself proceeded without a hitch and as smoothly as possible. Without observation of the guidelines it could not have been carried out as planned. Which is why the ideal of rigid adherence was valued in every way.

Photograph four shows seriousness dressed up as a game. In the thick of activity a mealtime was presumably an anticipated and significant event. The soldier lads were served food by young girls or Lotta Svärd lassies, also known as Little Lottas. One of the boys, second from the left, is very small, and all the other boy soldiers were also very young. Nevertheless, they seem to be taking part in the activity heart and soul. This is a very important element in the existential framework of the entire structure. The educational importance of playfulness can never be overemphasized. Seriousness will appear later in everybody's life anyway. Its arrival should not be expedited too early. In each human life childhood occurs just once. Its value should be cherished and fostered.

\section{Conclusion}

To end the day there was a need to gather together, to calm down and perhaps even be silent. A photograph is able to convey the essence of this moment.

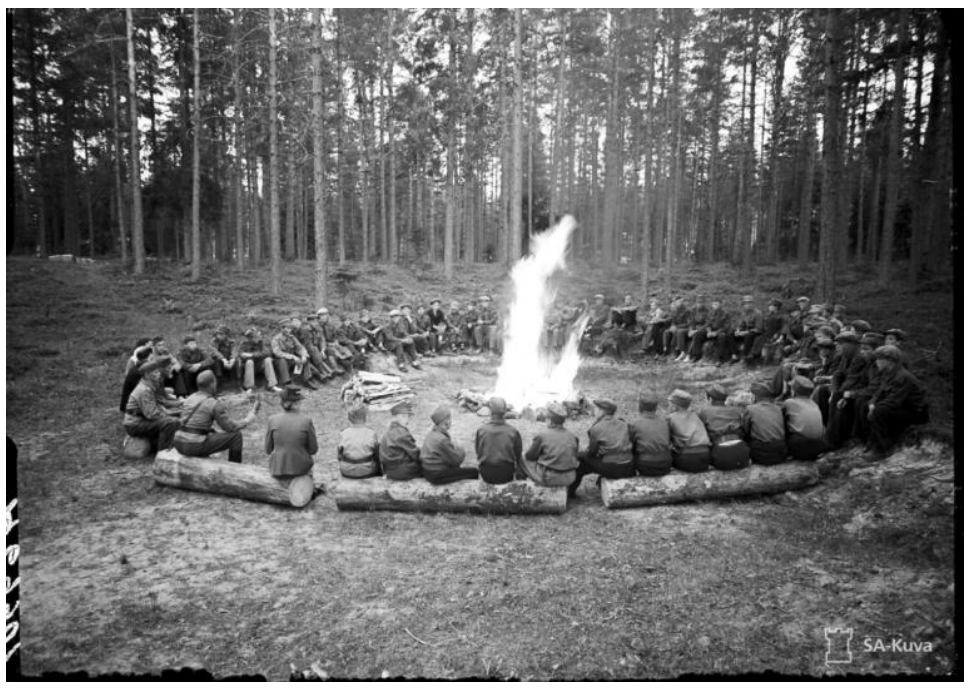

Photograph 5. In the glow of the time-fire

A time-snap review realized in the glow of a time-fire: Is it then just a matter of futilely repeating the word 'time'? Or does this procedure point to some innovation achieved through experimentation and research? A researcher must always be able to be honest, at least to himself. This is why I now dare to argue that a time-snap review is a sincere attempt to 
produce a nationally insightful totality for self-examination. For this we need language, picture, language pictures (=metaphors) and a picture language (=imagery).

Photograph 5 presents a multi-level existential arrangement, circular in form. The background displays an expanse of pine and spruce forest. Sections of the trunk of a felled tree, stones and the bare earth act as seats. And amidst everything the flames of a blazing fire. The end result gives the impression of having been carefully thought out and deliberately constructed. Yet it is also restful, thought-provoking and beautiful. In the outer ring there are people sitting. The inner circle surrounds the blazing fire. Back then in the war years did people think about the symbolism of the concentric circles of life? It is hard to believe that this was mere coincidence.

I need the help of Marti $\mathrm{H}$. Haavio, erstwhile doctor of theology and later also professor, for a more thorough consideration of the matter. Haavio's The Teacher Personality would seem to be an ideally suited guide to further deliberation. In characterizing the importance of aesthetic life Haavio draws some interesting conclusions: "In the aesthetically cultivated teacher there is something fresh and flexible which survives into old age. He rediscovers his enthusiasm over and over again." (Haavio, 1948, p. 65.) Photograph 5 is indeed an aesthetic shot. Yes, there would be no hesitation in also calling it an art photograph.

Perhaps at this point it would be best to ignore every possible manipulative goal. Of course, it has to be admitted that the influence of the era, i.e. the continuation war, probably played a part in all educational activities. Patriotism was also certainly an undercurrent in the harmonious existential atmosphere displayed in photograph 5 . Nevertheless I would say that the adults in the picture have been brought up, at least in some way, to be aesthetically cultivated, civilized. Even though a uniform imposes obligations on its wearer, it does not completely remove the cultivated side of a human being. Probably all the people sitting there on a summer evening were equally enthusiastic about joining in a campfire sing-song. Hopefully the soldier boys were also able to carry their freshness and flexibility in their attitudes to life into their adult years. Then the joyful twinkle in their eyes would not have disappeared even when they were grown older. Even after many years they could return to the blaze of the time-fire. Its radiated warmth was timeless.

"Always be valiant, cheerful and honest!" could also be the professionally-cultured motto of an essayist grasping for profundity. And that is something which this philosophical one-man editorial team will not forget. It will also be the starting point for any future cultural reviews - combined with a hint of poetry.

\section{Postscript}

\section{The 1918 Finnish civil war now?}

\section{A poetic study of remembering, forgetting and recurrence}

A ring or a circle is perfect in form: each contains a beginning and an end as well as a departure and arrival. The relatives of the circle are the ball and roundness. It is as consistent with itself as is possible - without a before and after element. It also lacks spaciality because being above or below is not part of its essential nature. A ring indicates some kind of state of peacefulness and restraint.

The recurring circles of existence are constantly present. This is why a person carries the national yesteryear in his essential being. The time dictates whether fellow co-existers are friends or enemies. Good as well as evil recurs. Does a person anyhow learn anything at all? Or is he at an unending beginning which evolves into the next ending? (For more on the topic of recurrence, see also Itkonen, 1993a; 1993b; 2018; Nietzsche, 1995; Stambaugh, 1972.) Perhaps a poetic study of humanity is able to answer the question of existence:

\section{Look at}

me,

take a close look.

I am the same boy

with whom 
from the rain-soaked asphalt.

We walked the lakeshore,

as anglers, as friends, as indians.

We shared a tent together

and continued our hike.

We were intoxicated with the gleam of the evening sun

and grew tired as the reeds hummed.

Who broke the spell

and sowed the seed of violence?

Or more correctly

took the past we acquired long ago

and changed it into the present.

Time repeated itself;

and you seized your grandad's gun.

I was the same enemy

who sometimes fell by the wayside.

I retold countless destinies,

I was a collective tear drop,

the pain of the past made present.

And yet I was the same me:

your childhood friend

that breathed in rhythm with you.

Bury me the way you also lost me:

Bright-eyed and face-to-face.

English translation by Glyn Hughes

\section{Remarks}

All the photographs were taken on courses arranged by the Savonlinna Military District soldier boys' group leader. The courses were arranged in Warkaus (modern spelling Varkaus) between June 28th and July 6th 1942. The course leader was lieutenant Juntunen. (For more detail see http://sa-kuva.fil.) 


\section{References}

[1] Haavio, M. (1948). Opettajapersoonallisuus. [The teacher personality]. Jyväskylä: Gummerus.

[2] Itkonen, M. (1993a). Minulta teille? Fenomenologinen analyysi käymättömästä keskustelusta. [From me to you? A phenomenological analysis of a conversation that did not take place]. Tampereen opettajankoulutuslaitoksen julkaisuja A 17. Tampere: Tampereen yliopisto.

[3] Itkonen, M. (1993b). Minä ymmärrän. Allegoria tiedonpölyn laskeutumisesta. [l understand. The allegory of the settling of informational dust]. In: Pohdin 8. Filosofinen aikakauskirja. Ed. J. Varto. Filosofisia tutkimuksia Tampereen yliopistosta (FITTY), volume 42. Tampere: Tampereen yliopisto, pp. 36-44.

[4] Itkonen, M. (2018). Sormunen, Itkonen ja murroskohtien Suomi. Kokeellisia tutkielmia henkisen kulttuurin tilasta. [Sormunen, Itkonen and the Finland of critical changes. Experimental studies into the state of intellectual culture]. In: Kokeellinen kameleonttikuluttaja. Kokemuksellisia tutkimusmatkoja satavuotiaaseen Suomeen. [The experimental chameleon consumer. Experiential expeditions into centennial Finland]. Eds. M. Itkonen, V. A. Heikkinen ja S. Inkinen. Haaga-Helian julkaisuja 5/2018. Helsinki: Haaga-Helia ammattikorkeakoulu, pp. 1182.

[5] Malmgren, E. (1928/1939). Muonituslotan käsikirja. [The Lotta Svärd Catering Handbook]. 5th impression. LottaSvärd julkaisu n:o 10. Helsinki: Lotta-Svärd.

[6] Nietzsche, F. (1883-1891/1995). Näin puhui Zarathustra. Kirja kaikille eikä kenellekään. [Thus spoke Zarathustra. A book for all and none]. Finnish translation by J. A. Hollo. $6^{\text {th }}$ edition. Helsinki: Otava.

[7] Pihkala. (2018). Lauri "Tahko" Pihkala. Päivän humanisti 6.1.2015. 375 humanistia. Helsingin yliopiston humanistinen tiedekunta. [Lauri "Tahko" Pihkala. Today's humanist 6.1.2015. 375 humanists]. Retrieved 23.1.2019 from http://375humanistia.helsinki.fi/humanistit/lauri-tahko-pihkala.

[8] Salo, A. (1952). Johdatus yleiseen kasvatusoppiin. [Introduction to general education]. Helsinki: Otava.

[9] Salomaa, J. E. (1942). Suunta ja tie. Kansalaiskasvatuksen perusteita. [The direction and the road. The basics of civic education]. Lotta Svärd julkaisu n:o 57. Helsinki: Lotta Svärd järjestön Keskusjohtokunta.

[10] Sotilas. 1922). (Sotilaskeittokirja. [The military cookbook]. Ed. Sotaministeriön intendenttiosaston muonitustoimisto. [Catering office, Ministry of Defence commissary]. Helsinki: Puolustusministeriön Intendenttiosasto.

[11] Stambaugh, J. (1972). Nietzsche's Thought of Eternal Return. Baltimore: Johns Hopkins University Press.

\section{Picture sources}

\section{SA picture archive, From the front line to the home front 1939-1945}

Photographs 1-5. Photographer P. Jänis. Retrievable at $\underline{h t t p: / / s a-k u v a . f i l}$. 